\title{
Honderd Jaar Hervormde Teologie
}

\begin{tabular}{|c|c|}
\hline \multicolumn{2}{|c|}{$\begin{array}{l}\text { Author: } \\
\text { Wim A. Dreyer }{ }^{1}\end{array}$} \\
\hline $\begin{array}{l}\text { Affiliation: } \\
{ }^{1} \text { Department } \mathrm{C} \\
\text { History and Ch } \\
\text { Faculty of The } \\
\text { University of P } \\
\text { South Africa }\end{array}$ & $\begin{array}{l}\text { f Church } \\
\text { nurch Polity, } \\
\text { ology, } \\
\text { retoria, }\end{array}$ \\
\hline \multicolumn{2}{|c|}{$\begin{array}{l}\text { Research Project Registration: } \\
\text { Project Leader: W.A. Dreyer } \\
\text { Project Number: } 77370920\end{array}$} \\
\hline \multicolumn{2}{|c|}{$\begin{array}{l}\text { This research is part of the } \\
\text { project, 'History of the } \\
\text { Afrikaans churches' } \\
\text { theology'/Teologiegeskiedenis } \\
\text { van die Afrikaanse kerke, } \\
\text { directed by Dr W. Dreyer, } \\
\text { Department of Church History } \\
\text { and Church Polity, Faculty } \\
\text { of Theology, University } \\
\text { of Pretoria. }\end{array}$} \\
\hline \multicolumn{2}{|c|}{$\begin{array}{l}\text { Corresponding author: } \\
\text { Wim Dreyer, } \\
\text { wim.dreyer@up.ac.za }\end{array}$} \\
\hline $\begin{array}{l}\text { Dates: } \\
\text { Received: } 28 \mathrm{~A} \\
\text { Accepted: } 24 \mathrm{~J} \\
\text { Published: } 29\end{array}$ & $\begin{array}{l}\text { Apr. } 2017 \\
\text { June } 2017 \\
\text { Sept. } 2017\end{array}$ \\
\hline \multicolumn{2}{|c|}{$\begin{array}{l}\text { How to cite this article: } \\
\text { Dreyer, W.A., 2017, 'Honderd } \\
\text { Jaar Hervormde Teologie', } \\
\text { HTS Teologiese Studies/ } \\
\text { Theological Studies 73(1), } \\
\text { a4612. https://doi. } \\
\text { org/10.4102/hts.v73i1.4612 }\end{array}$} \\
\hline \multicolumn{2}{|c|}{$\begin{array}{l}\text { Copyright: } \\
\text { ( 2017. The Authors. } \\
\text { Licensee: AOSIS. This } \\
\text { is licensed under the } \\
\text { Creative Commons } \\
\text { Attribution License. }\end{array}$} \\
\hline \multicolumn{2}{|l|}{ Read online: } \\
\hline 品ping & $\begin{array}{l}\text { Scan this QR } \\
\text { code with your } \\
\text { smart phone or } \\
\text { mobile device } \\
\text { to read online. }\end{array}$ \\
\hline
\end{tabular}

The Faculty of Theology of the University of Pretoria is celebrating its centenary during 2017. Since its inception in 1917, the Nederduitsch Hervormde Kerk van Afrika (by agreement) appointed lecturers in the Faculty and more than a thousand ministers of the Hervormde Kerk received their theological education at the University of Pretoria. As such, the centenary of the Faculty is also a celebration of hundred years of 'Hervormde theology'. This contribution reflects on two publications (by M.J. Goddefroy and P.J .Muller, respectively) which appeared in 1890 and 1908, firstly to give an overview of the prehistory of the establishment of the Faculty of Theology and secondly to illustrate the diverse origins and nature of Hervormde theology as reflected in the publications of Goddefroy and Muller.

\section{Inleidend}

Die titel van hierdie artikel en spesiale versameling in die HTS Hervormde Teologiese Studies is 'Honderd Jaar Hervormde Teologie'. Die titel opsigself is problematies. Vanselfsprekend kan mens nie in die bestek van een artikel, of selfs 'n versameling artikels, enigsins reg laat geskied aan honderd jaar se teologiese bydraes nie. Ten minste moet hierdie artikel saam met die ander artikels in hierdie spesiale versameling van HTS Teologiese Studies gelees word. Die onderskeie bydraes gee verskillende perspektiewe op Hervormde teologie.

Daarbenewens was daar nog altyd 'n terughoudenheid om van 'Hervormde' teologie te praat. In die Hervormde Kerk en teologie is eerder van 'Bybels-reformatoriese' teologie gepraat (Koekemoer 1994:19; Oberholzer 1993:880). Die terughoudenheid om van 'Hervormde' teologie te praat is nie onvanpas nie. Die diversiteit binne Hervormde teologie en die feit dat daar die afgelope honderd jaar konstant nuwe invloede in Hervormde teologie te bemerk is, laat tereg die vraag ontstaan of mens van 'Hervormde teologie' kan praat. Om dit te beantwoord, sal dit nodig wees om 'n omvattende historiese ondersoek te doen na die ontwikkeling en verandering wat Hervormde teologie sedert die negentiende eeu ondergaan het, iets wat buite die bestek van hierdie artikel val.

Indien iemand wel só 'n omvattende historiese ondersoek sou onderneem, is die een ligpunt die beskikbaarheid van bronne. Die eerste belangrike bron vir die bestudering van Hervormde teologiegeskiedenis is die groot getal artikels van individuele teoloë wat in die digitale argiewe van die Hervormde Teologiese Studies ${ }^{1}$ opgeneem is. Deur toedoen van die redakteur van HTS (Prof A.G. van Aarde) en befondsing deur die Hervormde Kerk, is die artikels wat sedert 1944 in die HTS gepubliseer is, gedigitiseer. Veral die vroeë uitgawes van die HTS bevat hoofsaaklik artikels van Hervormde teoloë (in Afrikaans) en gee'n goeie beeld van die teologie wat in die verskillende vakdissiplines beoefen is. Vanaf 2009 (toe HTS aanlyn beskikbaar geword het) tot 2015 het 4767707 (tans reeds meer as vyf miljoen) lesers uit 163 lande artikels afgelaai. HTS is tans 'n megajoernaal wat meer as 200 artikels per jaar publiseer en een van die mees gesiteerde teologiese joernale wêreldwyd (Van Aarde 2017: 70-71). Van die bekendste teoloë in die wêreld het al in HTS gepubliseer.

'n Tweede bron vir die bestudering van Hervormde teologiegeskiedenis, is Hervormde Teologiese Studies 48/1 \& 2, 'n jubileum uitgawe wat met die 75-jarige fees van die Fakulteit Teologie verskyn het. Die twee aflewerings van HTS bevat artikels oor die verskillende departemente en die bydrae van die dosente in die verskillende teologiese dissiplines en dien as goeie bron om die Hervormde teologiegeskiedenis na te gaan.

'n Derde bron vir die bestudering van Hervormde teologiegeskiedenis is 'n bundel opstelle wat in 1999 verskyn het onder die titel 20ste Eeu Hervormde Teologie (sien Van Wyk 1999). Hoewel baie van die bydraes meer informeel van aard is, kom daar waardevolle perspektiewe en gesprek oor Hervormde teologie na vore.

1.Die Hervormde Teologiese Studies is die oudste teologiese tydskrif in Suid-Afrika. Die argiewe van die HTS is gratis beskikbaar, toeganklik en kan maklik afgelaai word. Dit kan gevind word by http://www.hts.org.za/index.php/hts/issue/archive 
'n Vierde bron vir die bestudering van Hervormde teologiegeskiedenis is HTS Supplementum 9 (sien Oberholzer 2010) onder die titel Honderd Jaar Kerk en Teologiese Opleiding: 'n Kroniek van die Hervormde Kerk, wat 'n kronologiese beskrywing gee van die handelinge van die Kuratorium van die Hervormde Kerk, insluitend aantekeninge oor die verskillende dosente wat aan die Fakulteit doseer het. Die Supplementum van Oberholzer is aanlyn beskikbaar ${ }^{2}$ en het al meer as 35000 lesers getrek.

'n Vyfde bron is die memoranda wat by die Algemene Kerkvergaderings gedien het, asook kerklike tydskrifte en publikasies wat in die Kerkargief in Pretoria bewaar word.

Laastens kan die navorsing van onder andere J.A. Loader (1984) en C.J. Beukes (2000), wat in hulle proefskrifte onder andere aan die ontwikkeling voortgang van Hervormde teologie aandag gegee het.

In bogenoemde bronne vind mens sporadies pogings om tot ' $n$ bepaalde verstaan van die historiese ontwikkeling en eieaardighede van 'Hervormde teologie' te kom. Tog moet elke geslag teoloë dit opnuut doen (Oberholzer 1992:493). Nóú is weer ' $n$ geleentheid om bestek op te neem, en wel om drie redes.

Eerstens herdenk die Universiteit van Pretoria deur die loop van 2017 die stigting van die Fakulteit Teologie honderd jaar gelede (1917). 'n Gedenkblad (sien Duncan 2017) het pas verskyn wat hierdie geskiedenis in woord en beeld vertel. Elke eeufees is 'n geleentheid om terug te kyk, te evalueer en ook vorentoe te kyk.

Tweedens herdenk reformatoriese kerke wêreldwyd deur die loop van 2017 die Kerkhervorming wat in 1517 as gevolg van Martin Luther se teologiese arbeid aan die Universiteit van Wittenberg op dreef gekom het. Dit konfronteer byna vanselfsprekend elke reformatoriese teoloog met die vraag na die eie-aardigheid van reformatoriese (en per implikasie Hervormde) teologie.

Derdens is die verband tussen kerk en teologie onlosmaaklik. Die Nederduitsch Hervormde Kerk van Afrika (hierna: Hervormde Kerk) is sedert 2010 deur 'n moeilike periode, wat onder andere ' $n$ kerkskeuring ingesluit het. Een van die groot dryfvere agter die kerkskeuring was die beskuldiging van teologiese dwaling, teologiese liberalisme, bevrydingsteologie en 'ekumenistiese' teologie wat voor die deur van die Hervormde Kerk en die Fakulteit Teologie gelê is (sien in die verband Dreyer 2014). Standpunte en menings wat veral op sosiale media geplaas is, dui op grootskaalse onkunde of (doelbewuste?) eensydigheid oor 'Hervormde teologie'. Aan die ander kant het die Hervormde Kerk juis deur die smeltkroes van interne spanning en konflik groter duidelikheid gekry oor wat Hervormde teologie is, maar veral wat dit nié is nie. Dit blyk onder andere uit die besluite wat die 71e Algemene Kerkvergadering (sien NHKA 2016)

2.Supplementum 9 van die HTS Teologiese Studies is te vind by http://www.hts.org.za/ index.php/HTS/issue/view/39 oor kerkbegrip, ekumene, apostolaat en homoseksualiteit geneem het.

Ten spyte daarvan dat 'Hervormde teologie' 'n problematiese begrip is, wil ek tog daarmee volstaan juis omdat ek dit primêr as kerklike teologie verstaan. Ek steun ook op Johann Beukes (2008) se bydrae wat praat van 'n 'Hervormde benadering' tot teologie. Ek is van mening dat daar inderdaad iets soos 'n Hervormde benadering tot teologie is, wat onderskeibaar en selfs teenoor ander teologiese denkrigtings, bestaan. Hervormde teologie is iets anders as gereformeerde teologie, juis omdat dit put uit 'n wye spektrum van reformatoriese teologie. Hervormde teologie as reformatoriese teologie is dus nie suiwer 'Calvinisties' of 'gereformeerd' nie.

Die diversiteit in Hervormde teologie is opvallend as mens bogenoemde bronne nagaan. Uiteenlopende benaderings, perspektiewe en klemtone is opmerklik. Oor die meer as sewentig jaar van die HTS se bestaan, het daar artikels met uiteenlopende temas verskyn wat perspektiewe open vanuit reformatoriese teologie (Luther, Calvyn, Bullinger); konfessionele teologie (veral die Heidelbergse Kategismus); Nederlandse teologie (Groninger - en Etiese teologie); moderne teologie (veral Schleiermacher); eksegetiese studies (Ou - en Nuwe Testament); dialektiese teologie (Barth en Brunner); hermeneutiek (Bultmann, Fuchs en Ebeling); Nederlandse apostolaatsteologie (Kraemer); Nederlandse volkskerklike teologie (Hoedemaker en Van Ruler); narratiewe en post-liberale teologie (Hauerwas); historiese Jesus-navorsing (Van Aarde en Borg); sosiaalwetenskaplike eksegese (Malina) asook missionale teologie (David Bosch). Die grootste gemene deler ten opsigte van hierdie voorbeelde, is dat dit breedweg onder die noemer 'reformatories' geplaas kan word.

Vir iemand wat van buite kyk, kan dit na 'n vreemde mengelmoes lyk. Juis die diversiteit, openheid, kritiese ingesteldheid en gees van verdraagsaamheid wat in Hervormde teologie merkbaar is, vorm een van die kenmerkende hoekstene daarvan. Hervormde teologie is geen monolitiese, positivistiese of modernistiese denksisteem nie.

In hierdie bydrae beperk ek myself tot die periode voor die stigting van die Fakulteit Teologie in 1917. Vir ons verstaan van Hervormde teologie is die voor-geskiedenis (in Nederland en ook in Suid-Afrika) van groot belang. As deel van die voorgeskiedenis sal ek kortliks na die eerste twee teologiese publikasies uit Hervormde geledere verwys, te wete ds. M.J. Goddefroy (1890 [1990]) se De Kerkkwestie niet een Leer - maar een Levenskwestie asook dr P.J. Muller (1908) se Handboek der Dogmatiek, waarvan ek sy persoonlike kopie in my besit het. Hierdie publikasies dien as voorbeelde van negentiende eeuse Nederlandse teologie wat na Suid-Afrika verplant is. Goddefroy was predikant van die Hervormde Gemeente Pretoria (1888-1904); Muller hoogleraar aan die Universiteit van Amsterdam en predikant van die Hervormde Gemeente Pretoria (1904-1909). Dié twee Hervormde teoloë het baie in gemeen, maar verskil ook ingrypend van mekaar. Beide het in Nederland hulle teologiese opleiding gehad; 
beide het in die Nederlands Hervormde Kerk as predikante gedien; beide het as predikant van die Nederduitsch Hervormde Gemeente Pretoria gedien; beide was uitgesproke voorstanders van teologiese opleiding aan 'n volwaardige teologiese fakulteit aan ' $n$ universiteit; beide het as voorsitter van die Algemene Kerkvergadering gedien en beide was passievol oor die Hervormde Kerk en Hervormde teologie. Ten spyte van al dié ooreenkomste, het hulle teologie op uiteenlopende wyses beoefen. Miskien is dit juis sprekend van die eenheid in diversiteit wat Hervormde teologie vertoon.

\section{Teologiese strominge in Nederland gedurende die negentiende $e^{3} u^{3}$}

Hervormde teologie is vanselfsprekend ouer as die Fakulteit Teologie. Die eie-aardigheid van Hervormde teologie kan nie verklaar word sonder om die direkte verbintenis met die Nederlandse teologie van die negentiende en begin van die twintigste eeu aan te toon nie. Die predikante wat tussen 1852 en 1902 in die Zuid-Afrikaansche Republiek in die Hervormde Kerk diens gedoen het, het almal hulle teologiese opleiding aan Nederlandse universiteite ondergaan, behalwe uitsonderlike gevalle waar hulle opleiding in Stellenbosch ontvang het.

Die Nederlandse Hervormde Kerk is deur die loop van die negentiende eeu gekonfronteer met uiteenlopende teologiese denkrigtings, wat vanuit verskillende teologiese fakulteite gekom het. Dit sluit onder andere die Groninger-teologie, etiese teologie, konfessionele teologie en modernistiese teologie in. Daarnaas het die Nederlands Hervormde Kerk twee afskeidings beleef, in 1833 en weer in 1885 onder leiding van Abraham Kuyper.

Ds. Dirk van der Hoff, wat aan die Universiteit van Leiden studeer het (Engelbrecht 1953b:80), was die eerste Nederlandse predikant wat vanaf 1853 in die ZAR diens gedoen het. Daarna volg A.J. Begemann en G.W. Smits (vanaf 1861) asook N.J. van Warmelo (vanaf 1863). Van Warmelo het ook in Leiden studeer, waar hy veral deur JH Scholten beïnloed is (Pont 1955:1925). In hierdie tyd was daar 'n groot getal beroepafwagtende proponente in Nederland, insluitende Van der Hoff, Smits, Begemann en Van Warmelo (sien Pont 1955:31). Ten spyte daarvan dat Smits, Begemann en Van Warmelo uit ou predikante-families stam en in pastorieë grootgeword het, is hulle nie beroep nie. Proponente in Nederland het dikwels jare vir 'n beroep gewag en daarom was hulle bereid om na Amerika, Oos-Indië, Australasië en Suid-Afrika te verhuis. Daar was ook diensdoenende predikante wat bereid was om na die ZAR te verhuis (bv. M.J. Goddefroy), ten spyte van die pioniersomstandighede waaraan hulle blootgestel is.

Haitjema (1931:32) is van mening dat die Fakulteit Teologie aan die Rijksuniversiteit van Groningen vir die grootste gedeelte van die negentiende eeu die toon aangegee het. Die 3.Vir'n omvattende beskrywing hiervan sien Rasker (1974); a a oook Haitjema (1964).
Groninger-teologie, veral onder invloed van Hofstede te Groot, is beskou as 'n eg Nederlandse, vaderlandse en evangeliese teologie met sterk nasionalistiese ondertone. Interessant genoeg is dit ' $n$ teologiese benadering wat histories teruggevoer kan word na die Nederlanders Wessel Gansvoort, Erasmus van Rotterdam en Jacob Arminius (Haitjema 1931:32). Miskien is dit ook relevant om op te merk dat Groningen en Emden slegs sewentig kilometer van mekaar is. Die Sinode van Emden het in 1571 die Nederduitsche kerk op vaste fondamente geplaas met die aanvaarding van die Nederlandse Geloofsbelydenis, die Heidelbergse Kategismus en voorlopige kerkordelike reëlings.

Haitjema $^{4}$ (1931:33) is verder van mening dat die Groningerteologie teen 1870 invloed verloor het, veral onder druk van J.H. Scholten in Leiden. Na 1870 ontwikkel die 'etiese rigting' in die Groninger-teologie as eg Nederlandse teologie. Dit het later aanklank gevind by die dialektiek van Sören Kierkegaard en die dialektiese teologie van Brunner en Barth. Die etiese rigting ontleen sy naam nie van die woord 'ethica' nie, maar van 'ethos' [wese]. Dit gaan dus oor die wese van die waarheid (Loader 1987:48). Wat daarmee bedoel word is dat die waarheid wesenlik nie objektiveerbaar of rasionaliseerbaar is nie. Die waarheid is nie objektief in ' $n$ teks (soos die Bybel) te vind nie, maar eerder in die ontmoetingsgebeure tussen God en mens in Christus. Die mens het toegang tot die waarheid deur die inkarnasie van Christus wat die ontmoeting met God (en waarheid) moontlik maak (Loader 1987:49). Dit beteken dat die waarheid nóg in die kerklike leer nóg deur die menslike rede vasgevang kan word. Hierdie waarheidsbegrip spruit uit 'n bepaalde verstaan van openbaring, menslike ervaring en werklikheid. Die ervaring is die ontmoeting met Christus. Hierdie etiese waarheidsbegrip het kritiek ontlok van liberale sowel as ortodokse teoloë. Die etiese rigting was te behoudend vir die moderniste en te vrysinnig vir die tradisionaliste.

'n Ander aspek van die etiese rigting wat van groot belang vir die teologiegeskiedenis van die Hervormde Kerk is, is die sentrale plek wat die kerk en die gemeente in die etiese teologie inneem. In ooreenstemming met Schleiermacher het De la Saussaye sy teologie 'vanuit die gemeente en vir die gemeente' beoefen (Rasker 1974:133).

Kritiek vanuit die liberale teologie teen 'n relasionele waarheidsbegrip is te verstane. Liberale teologie was 'n produk van die Aufklärung wat gestreef het na objektiewe en eksakte kennis. Die leiersfigure in die liberale teologie in Nederland was C.W. Opzoomer en J.H. Scholten. Opzoomer (1821-1892) was juris en van 1846 tot 1889 dosent in filosofie wat in Nederland ' $n$ besondere invloed op die ontwikkeling van die moderne teologie gehad het. Hy stel dat die mens deur rasionele denke tot kennis van God kan kom. Daar is vir

4.Th L Haitjema is vanaf 1923 as kerklike hoogleraar aan die Universiteit van Groningen aangestel. Hy was verantwoordellk daarvoor dat die denke van Karl Barth in Groningen bekend geword het. Predikante vanuit die Ned. Hervormde Kerk van Afrika wat aan Groningen studeer het (bv. H.P. Wolmarans), het vroeg reeds met di dialektiese teologie in aanraking gekom. Wolmarans het in 1932 onder leiding van WJ Aalders ('n etiese teoloog) in godsdiensfilosofie gepromoveer oor Brunner se verstaan van die 'Die beeld van God in die mens'. 
hom geen onderskeid tussen die rede en geloof nie. God staan nie teenoor die natuur nie. Dit maak dat hy skepties staan teenoor bonatuurlike wonderwerke (Rasker 1974:114).

Scholten begin sy studies in Utrecht en word later (1843) as dosent aan die Universiteit van Leiden aangestel. Daar het hy stelselmatig wegbeweeg van 'n meer tradisionele teologie na 'n modernistiese teologie. Hy was byvoorbeeld daarvan oortuig dat die rede die enigste bron van kennis oor God is. Die Bybel is slegs ' $n$ historiese kenbron van die Christelike geloof, maar bevat geen gesag insigself nie. Die Heilige Gees is die waarborg van die boodskap, maar die Heilige Gees en die rede word gelyk aan mekaar gestel. Scholten het 'n histories-kritiese benadering ontwikkel om sodoende die Ou Testament deur middel van 'n evolusionistiese model te verklaar (Rasker 1974:119). Hierdie benadering is vanuit etiese kringe gekritiseer, omdat sy monistiese teologie geen onderskeid tussen geloofs- en wetenskaplike kennis gemaak het nie.

Aan die ander kant van die teologiese spektrum het die ortodokse rigting beswaar gehad teen die gebruik van die histories-kritiese metode van die liberale en etiese rigtings. Twee van die bekendste teoloë uit die ortodokse rigting was H.F. Köhlbrugge en P.J. Hoedemaker. Köhlbrugge (18031875) se teologie kan as verbondsteologie beskryf word. Hy was van mening dat daar geen onderskeid tussen die $\mathrm{Ou}-$ en Nuwe Testament is nie. Mens sien dit in sy proefskrif oor Psalm 45 wat hy 'n 'huwelikslied' vir Christus noem. Köhlbrugge grens homself af teen beide die piëtistiese en die histories-kritiese bewegings. Hy stry teen alles wat die plek van God se genade wil inneem (sien Rasker 1974:106-110).

Hoedemaker (1839-1910) se ouers was aanvanklik lidmate van 'n afgeskeie gemeente in Utrecht. Toe Hoedemaker twaalf jaar oud was het sy ouers na Michigan in die VSA geemigreer. Hoedemaker begin sy teologiese studies aan ' $n$ seminarium van die Reformed Church in New Brunswick waar hy onder invloed van die invloedryke filosoof, teoloog en digter RW Emerson kom. Dat hy Emerson persoonlik geken het blyk uit die voorblad van sy proefskrif wat hy aan die Universiteit van Utrecht voltooi het, waarin hy die proefskrif aan Ralph Waldo Emerson opdra vir sy 'kind appreciation of my boyish efforts, and the impetus he has given towards my studies as well as the influence he has had on my mind' (sien Haitjema 1964:282). Emerson het sy opleiding aan Harvard Divinity School gehad. Hy was bekend vir sy transendentalisme en die weerstand wat hy gebied teen die invloed van Jonathan Edwards se Neo-Calvinisme. Emerson het 'n bepaalde kennis en waardering gehad vir die filosofie van Immanuel Kant, Leibnitz, Fichte en Schelling.

Met Hoedemaker se terugkeer na Nederland studeer hy verder aan Utrecht en promoveer in 1867 onder Van Oosterzee. In sy vroeë skryfwerk blyk 'n bepaalde affiniteit vir die etiese rigting, by name De la Saussaye en Gunning, veral hulle verstaan van die openbaring in die inkarnasie van Christus (Haitjema 1964:285). Stelselmatig het Hoedemaker hom weggekeer van die etiese rigting en toenemend Abraham
Kuyper se rigting ondersteun. Deur Kuyper se toedoen word Hoedemaker in 1876 na Amsterdam beroep waar hy saam met Kuyper werk aan die oprigting van die Vrije Universiteit. Hy was een van die eerste drie dosente wat in 1886 aan die Vrije Universiteit aangestel is (Rasker 1974:255).

Tot 1886 staan Hoedemaker aan die sy van Kuyper in die stryd teen die modernisme. Spoedig het hy 'n afkeer aan Kuyper se partypolitieke ingesteldheid ontwikkel asook Kuyper se strewe na 'n konfederatiewe kerkverband. Hy beweeg in die tyd toenemend op die spoor van Groen van Pinsterer, wat die gedagte van die volkskerk en die 'Christelike nasie' propageer (Rasker 1974:256). Reeds in 1887 bedank Hoedemaker as hoogleraar van die Vrije Universiteit Amsterdam, word beroep na Nijland en twee jaar later weer na die Hervormde Kerk Amsterdam. Daar het hy sy program 'reformatie door reorganisatie' vir 'heel den volk en heel den kerk' bevorder.

Met hierdie uiters kort en onbevredigende oorsig oor enkele teologiese strominge in Nederland, kan ons nou kyk hoe dit na Pretoria verplant het, onder andere deur die toedoen van Goddefroy en Muller.

\section{M.J. Goddefroy ${ }^{5}$}

Goddefroy is in 1848 in Brussel, België gebore en is van Franse herkoms. Hy studeer teologie aan die Universiteit van Utrecht tussen 1871 en 1876. Goddefroy het homself tuis gevind in die denke van proff Doedes, Van Oosterzee ${ }^{6}$ en Beets, wat die gesag van die Skrif onvoorwaardelik gehandhaaf het. Volgens getuienis van studente het Doedes by hulle 'n eksegetiese gewete ingeskerp deur die klem te plaas op kritiese en grammaties-historiese eksegese (Botha 1981:12-13). Van Oosterzee was dié kanselredenaar van sy tyd en sy groot ideaal was om predikante vir die kerk op te lei wat die Bybel gelowig en met toewyding sou verkondig. By Beets het Goddefroy Kerkgeskiedenis geleer, asook 'n afkeur aan partyskappe en kerklike twis.

Goddefroy het verder 'n groot belangstelling in letterkunde en filosofie gehad en het aan verskillende studenteverenigings behoort. Hy het persoonlik met die filosoof Opzoomer te doen gekry, wat hom geleer het om altyd krities na sake te kyk. Opzoomer het as filosoof groot invloed uitgeoefen op die ontwikkeling van die moderne teologie in Nederland. Goddefroy het dus as student blootstelling aan sowel die meer ortodoks-konfessionele as die moderne teologie en filosofie gehad. Na sy studie het Goddefroy drie gemeentes van die Nederlands Hervormde Kerk bedien (1877-1887). Goddefroy het te midde van die kerklike en teologiese stryd in Nederland hom na twee kante afgegrens, teenoor die afskeidingsbeweging van Abraham Kuyper en die modernistiese teologie. Tegelykertyd het hy baie tyd en 5.Vir'n omvattende beskrywing van Goddefoy se lewe en werk sien Botha (1979).

6.Prof T.F.J. Dreyer, hoogleraar (emeritus) aan die Universiteit van Pretoria in Praktiese Teologie en verskeie termyne voorsitter van die Algemene Kerkvergadering van die Ned. Hervormde Kerk het in 1974 sy doktorale proefskrif aan die Universiteit van Utrecht voltooi oor Van Oosterzee as homileet. 
energie spandeer aan die vestiging en ontwikkeling van Christelike onderwys (sien Botha 1981:24-52).

Na die pogings om die NG Kerk en die Hervormde Kerk in die ZAR te verenig misluk het, was daar 'n groot behoefte aan 'n predikant wat kon leiding gee in die heropbou van die Hervormde Kerk (sien Botha 1981:53-100). Goddefroy het in 1888 die beroep na die Hervormde Gemeente Pretoria aanvaar. Hier aangekom, het hy hom vasgeloop teen die vyandigheid van die Verenigde Kerk en by name ds HS Bosman. Sy genoemde publikasie was 'n reaksie teen die beskuldiging van dwaalleer, vrysinnigheid, magsmisbruik en alleenheerskappy wat Bosman in die openbare pers teen hom ingebring het. Die beskuldiging van leervryheid is dieselfde wat voorheen deur Dirk Postma en Frans Lion Cachet teen Van der Hoff en die ander Hervormde predikante ingebring is (sien Dreyer 1999:119-154). Postma en Cachet was in Nederland deel van die afgeskeie gemeentes en Bosman het aan Stellenbosch sy teologiese opleiding gehad. Talle Kaapse predikante (ook Bosman) het 'n fundamentele wantroue in die Nederlandse Hervormde Kerk en Hervormde teologie gehad wat hulle as modernisties, liberaal en vrysinnig beskou het.

Goddefroy het De Kerkkwestie - Niet een leer - maar een levenskwestie (Goddefroy 1890 [1990]) geskryf om Bosman se beskuldigings van vrysinnigheid en dwaalleer te weerlê. Dit moet dus as geleentheidsgeskrif gelees word wat polemies van aard is. Ingevleg in die polemiek vind ons wesenlike teologiese uitgangspunte wat ons 'n blik gee op die tipe teologie wat Goddefroy beoefen het.

In die voorwoord van De Kerkkwestie (bl. 29) versoek Goddefroy Bosman om die gesprek op 'wetenskaplike vlak' te voer. Sy waardering vir teologie as wetenskaplike dissipline aan 'n Universiteit het hy reeds tydens die eerste Algemene Kerkvergadering wat hy in 1888 in Pretoria bygewoon het, verwoord:

Wij moeten een Hoogeschool hebben - geen Kweekschool ... een kweekschool is tegen ons Ned. Herv. beginsel. In onze kerk word nooit leeraars toegelaten of zij moesten hunne opleiding aan een werkelijke universiteit gehad hebben. (aangehaal deur Buitendag 2017:11)

Twintig jaar later, tydens die 34e Algemene Kerkvergadering (1909) was Goddefroy steeds uitgesproke teen die vestiging van 'n kweekskool om Hervormde predikante op te lei. Hy wou die opleidng van predikante aan 'n universiteit sien 'opdat zij een ruimer blik geeft en meer omgang met jongmannen van ander vakken' (aangehaal deur Oberholzer 2010:6). Goddefroy het gedurende sy studentejare in Utrecht 'n leidende rol gespeel in verskillende verenigings, selfs as voorsitter. Dit sluit filosofie en letterkunde verenigings in. Goddefroy se standpunt was dat teologiese opleiding in gesprek met ander wetenskappe moet geskied.

Die Transvaal University College het in 1908 geopen. Dit het later (1932) die Universiteit van Pretoria geword. Eersgenoemde datum het die moontlikheid van teologiese opleiding in Pretoria aan 'n universiteit geskep. Die Fakulteit Teologie het in 1917 amptelik met sy werksaamhede begin. Goddefroy kon nog voor sy dood in 1920 sy ideaal verwesenlik sien, naamlik die opleiding van Hervormde predikante aan 'n universiteit.

Vervolgens 'n paar opmerkings oor Goddefroy se teologie soos hy dit in De Kerkkwestie artikuleer. Reeds in die voorwoord van De Kerkkwestie (Goddefroy 1890 [1990]:27-29) kom iets van sy teologiese oriëntasie na vore. Goddefroy is positief oor kritiese teologiese gesprek: 'Kritiek is nodig en heilsaam ...', maar gekwalifiseerd: Dit moet opbouend wees, binne die grense van fatsoenlikheid en gedring deur Christelike liefde. Kritiek moet diensbaar wees aan die suiwer leer volgens die Skrif en 'die heil van ons onsterflike siele' (bl. 27).

Goddefroy wys daarop dat Bosman in sy 'sewe taamlike lang koerantartikels' homself voortdurend op Dordt, Calvyn en die kerkorde beroep, maar slegs een keer na die Bybel verwys. Hierdie fundamentele respek vir die Bybel as norma normans is nie net kenmerkend van Goddefroy se teologie nie, maar ook van Hervormde teologie in die algemeen (Oberholzer 1993:873). Dan vervolg Goddefroy: 'Is dit egter gereformeerd? Dan verkies ek om maar eerder Bybelgetrou regsinnig te wees'. Die beginsel dat die Bybel die norma normans en die belydenisskrifte norma normata is, werk hy in die daaropvolgende hoofstukke verder uit. Hervormde teologie het konsekwent hierdie onderskeid gehandhaaf, wat daartoe gelei het dat die Hervormde Kerk sigself nooit as 'belydeniskerk' beskou het nie, maar konsekwent as 'belydende kerk'.

Goddefroy (bl. 30) wys daarop dat Bosman die beskuldigings teen hom as 'n 'leerkwessie' aanbied, in die vaste oortuiging dat Goddefroy, omdat hy aan die Hervormde Kerk getrou wil bly, vrysinnig is en afwyk van die belydenisskrifte en die 'leer van die vadere'. Goddefroy teken beswaar aan dat die kontrovers baie spoedig nie meer oor die suiwer leer gegaan het nie, maar in persoonlike aanvalle ontaard het. Die ad hominem geskryf in die koerante het daartoe gelei dat die saak verlore gegaan het en dat 'die heer Bosman nie een enkele fundamentele leerstuk van die Ned Herv Kerk behandel nie. Nog die uitverkiesingsleer, die cor ecclesiae ..., nog die leer oor de sakramente'.

Bosman het kort-kort na die 'leer' van die kerk verwys, en dan is die woordjie telkens in vetdruk geplaas. Dit het vanselfsprekend die binding aan die belydenisskrifte op die tafel geplaas, waaraan Goddefroy in die bestek van 100 bladsye vanuit verskillende perspektiewe aandag gee. Goddefroy was deeglik bewus van die feit dat die belydenisskrifte (en spesifiek die Dordtse Leerreëls) onder die burgery in die ZAR en lidmate nie goed bekend was nie. Bosman skryf in een van sy artikels dat 'ons volk in murg en been Calvinisties en Dordtgesind is'; waarop Goddefroy antwoord:

Ook durf ek nie veronderstel dat baie van ons volk van byvoorbeeld Calvyn se Institusie ' $n$ bepaalde studie gemaak het 
nie. En wat Dordtgesind betref - ag kom nou! Daarvoor moes die Formuliere van Enigheid beter bekend gewees het ... (p. 31)

Daarmee slaan Goddefroy die opvatting dat die Transvaalse Afrikaners 'van nature' Calvinisties sou wees volgens die Dordtse weergawe daarvan, die nek in. Dit is ' $n$ mite wat later weer onder invloed van J.D. du Toit (Totius) en Kuyperiaanse gereformeerde teologie herleef het (sien byvoorbeeld Snyman 2015:s.p.).

Goddefroy staan afwysend teenoor die gebruik om na 'n kerk of 'n volk as 'Calvinisties' te verwys. Hy skryf soos volg:

Dat hy deur en deur Calvinisties is, is ook nie die hoogste lof wat 'n mens aan 'n volk kan gee nie. 'Christianus mihi nomen Reformatus cognomen'7 is 'n spreuk uit die bloeityd van die Hervorming. Nie Luther en Calvyn nie, maar Christus Jesus is die enigste naam, wat onder die hemel gegee is waardeur sondaars gered sal kan word. (bl. 32)

Hierdie gedagte, dat dit in die eerste plek om die evangelie en om Jesus Christus gaan en nie om die belydenisskrifte of Calvyn of die kerk nie, kom herhalend in De Kerkkwestie na vore. Daarmee gee Goddefroy 'n sterk Christosentriese vertrekpunt aan sy teologie.

Goddefroy behandel in sy boek van meer as honderd bladsye Skrifbeskouing, die verband tussen Skrif en belydenis, kennis van die belydenisskrifte, die quia / quatenus vraagstuk, kerkbegrip, die geskiedenis van die Hervormde Kerk in die ZAR en die Hervormde Kerk as die regmatige voortsetting van die staatskerk van die ZAR, die beskuldiging van bandeloosheid in leer en lewe en die vraag wat dan 'suiwer gereformeerd' is.

Dit is veral Bosman se verwysing na die 'gesuiwerde kerk' waarop Goddefroy snydend en amper minagtend reageer:

Die gesuiwerde kerk? Maar watter kerk word daarmee bedoel? Die Lutherse, Gereformeerde of 'n ander een? Die 'gesuiwerde kerk van alle eeue'? Daarmee kan feitlik niks anders bedoel word as die onsigbare, heilige, algemene Christelike kerk - die gemeente van Christus - nie. Maar wie sal nou vir ons presies kan sê wie daaraan behoort? Wel, sal ds. Bosman antwoord, daaraan behoort ongetwyfeld Augustinus, Calvyn en dr. Kuyper ... maar Hieronymus, Martin Luther en dr. Gunning, behoort hulle dan nie tot die gesuiwerde kerk van al die eeue nie? (bl. 37)

Uit hierdie aanhaling vind ons Goddefroy se afwysing van Kuyper en sy waardering vir Gunning (een van die grondlêers van die etiese teologie - sien Rasker 1974:139-152). Maar ons vind ook by Goddefroy' $n$ afwysing van oordrewe Calvinisme en waardering vir die breër reformatoriese tradisie, insluitend Luther. 'n 'Suiwer kerk' was vreemd aan Goddefroy se ekklesiologie, omdat (soos Calvyn dit formuleer) die kerk altyd corpus permixtum bly.

Goddefroy haal omvangryk aan vanuit die Kerkvaders, Reformatore, die belydenisskrifte, Nederlandse teoloë en

7.Vertaling: 'My naam is Christen, my bynaam is Hervormd'. Gooddefroy het waarskynlik die gedagte by sy leermeester Van Oosterzee in Utrecht leer ken, aangesien dit sy grafskrif was. kerklike dokumente. Daaruit blyk sy deeglike teologiese opleiding en kennis van primêre bronne. Een aanhaling wat vir hierdie bydrae van belang is, is sy instemmende verwysing na Thomas Burgers (Kaapse predikant en later president van die ZAR) se Schetsen uit Transvaal waarin Burgers oor die geaardheid van die 'Hervormde genoodschap' skryf. Goddefroy haal hom soos volg aan:

Hulle [die Hervormers] het die Kolonie juis in 'n tyd verlaat toe die streng Calvinisme begin het om sy invloed in die kerk alhier te laat geld en die vryere beginsels van die Hervormde Kerk te verdring ... En op al hul swerftogte het hulle vry gebly van al die skadelike invloede wat hier op die volk ingewerk het. Daar word inderdaad nie baie intelligensie vereis om by die eerste kennismaking van die kerk in Transvaal op te merk dat die geesdrywery van 'n hardnekkige en blinde dogmatisme, wat soos ' $n$ dodelike kanker in die hart van die koloniale kerk voortwoeker, nog nie vrye teuels in die Transvaal gehad het nie. Die meeste bly nog Hervormdes soos hulle uit die Kaapkolonie vertrek het. Hulle het nie die misterieuse oorgang van 'Hervormd' na 'Gereformeerd' gemaak nie. (bl. 59)

Vanselfsprekend het Burgers, wat in die Kaap as vrysinnig gebrandmerk is, se positiewe waardering van Hervormde teologie en die Hervormde Kerk hom die gramskap van baie op die hals gehaal. Dit reflekteer egter iets van wat besig was om te gebeur, naamlik 'n verwydering tussen die NG Kerk en die Hervormde Kerk vanweë verskille in teologiese vertrekpunte. In die Hervormde Kerk was daar min waardering vir 'n oordrewe Dordtse Calvinisme en belydenisdwang.

Ruimte ontbreek om verder op Goddefroy se teologie in te gaan. Sy uitgangspunt soos verwoord in De Kerkkwestie kan saamgevat word in die volgende formulering: 'Geen Christendom sonder Christus nie; geen kerk sonder belydenis nie, maar ook geen belydenis of formulier bo of naas die onbedrieglike Woord van die Here nie' (sien Botha 1890 [1990]:18).

\section{P.J. Muller ${ }^{8}$}

Aan die begin van die twintigste eeu, na die kerkvereniging van 1885 en 1886, die Tweede Vryheidsoorlog (1899-1902), die gepaardgaande vernietiging van die ZAR en die dood van ongeveer $30 \%$ van Hervormde lidmate, breek 'n nuwe era in die geskiedenis van die Hervormde Kerk aan. Wat teologiese opleiding betref, verskyn dr. P.J. Muller op die toneel wat besonder invloedryk was in die verdere ontwikkeling van die teologie en die Hervormde Kerk in die algemeen.

In 1903 het oudl. ADW Wolmarans Nederland besoek met die opdrag om 'n predikant vir die Hervormde Gemeente Pretoria te vind. Dit was nodig omdat ds M.J. Goddefroy op daardie stadium nog in Engelse strafkamp vir 'undesirables' in Fort Govindghur in die Pandjab (Indië) aangehou is en nie na die Transvaal kon terugkeer nie. Twee van Goddefroy se seuns is tydens die Tweede Vryheidsoorlog dood en die 8.Vir'n omvattende beskrywing van Muller se lewe en werk sien Mans (1967). 
ander twee (soos hy) is in konsentrasiekampe aangehou. Goddefroy het eers in 1904, sieklik en verbitterd, na SuidAfrika teruggekeer (sien Botha 1981:147-153).

In Nederland het Wolmarans met verskeie predikante kontak gemaak wat nie kans gesien het om na Pretoria 'n beroep te aanvaar nie. Hy maak ook met Muller kontak en in 'n skrywe aan Muller' (Mans 1967) gee Wolmarans die volgende beskrywing van die Hervormde Kerk:

Ons volk is tamelijk streng Kalvinistisch, doch wij moeten niet hebben de bekrompen Kalvinist, die bijvoorbeeld verbiedde 's Zondags per rijtuig kerkwaarts te gaan of kos te koken omdat de dienstboden moeten rusten overeenkomstig de Wet. Ook moet wij niet hebben zij die eerst Gods Woord willen verbeteren en dan 't overige neemt als Gods Woord. ... Doch wij moeten hebben een man die ondubbelzinnig verklaard de Bijbel aan te nemen als Gods Woord en als de enige fondament van ons tegenwoordige en toekomstige leven ... (p. 74)

Opvallend is dat Wolmarans ' $n$ 'middel-posisie' inneem: Aan die een kant wys hy die oordrewe, bekrompe Calvinisme af; aan die ander kant ook die Modernisme wat nie erns maak met die Bybel as die Woord van God nie. Ook uit hierdie aanhaling blyk dit dat die Hervormde Kerk en teologie afwysend gestaan het teenoor die Calvinistiese ortodoksie. $\mathrm{Na}$ gesprek met Wolmarans het Muller die beroep na Gemeente Pretoria aanvaar. Ouderling Wolmarans is deur verskeie Nederlanders gelukgewens dat hy Muller kon oorreed om na Pretoria te gaan, 'omdat hy 'n kragtige figuur is, onbekrompe maar wat tog ondubbelsinnig op die Konfessie staan' (sien korrespondensie soos aangehaal in Mans 1967:74-76). Muller is allerweë beskou as iemand wat teologies 'n 'middel-posisie' inneem.

Muller is in 1874 as teologiese student aan die Ryksuniversiteit van Groningen ingeskryf. Vyf jaar daarna, in 1879, lê hy die doktorale eksamen af. Hy bedien die Hervormde gemeente van Steenwijkerswold, promoveer op 27 Junie 1881 cum laude met 'n proefskrif oor De Godsleer van Calvijn uit religieus oogpunt beschouwd en gewaardeerd. Daarná bedien hy die Hervormde gemeentes van Wolsum, Nijmegen en Rotterdam. In 1890 word hy aangestel vanweë die Nederlands Hervormde Kerk aan die Stadsuniversiteit van Amsterdam waar hy Leerstellige Godgeleerdheid, Geschiedenis der Nederlandsche Hervormde Kerk en Zending doseer het.

Aan die einde van 1893 is hy eervol as hoogleraar ontslaan (Engelbrecht 1953a:271). Dit was die gevolg van Abraham Kuyper se optrede, wat in koalisie met ander partye in die stadsraad van Amsterdam besluit het dat daar nie nog 'n teologiese fakulteit in Amsterdam naas die Vrije Universiteit behoort te wees nie. As parlementslid, Minister van Binnelands Sake en later as Eerste Minister het Kuyper 'n geweldige rol in die Nederlandse samelewing gespeel. By aanstelling van teologiese dosente is voorkeur gegee aan lede van Kuyper se Antirewolusionêre Party, die rede waarom Muller teen alle verwagting nie vir Lamers by Utrecht opgevolg het nie. Muller was teen Kuyper en die Doleansie 9.NHKA Kerkargief Pretoria, G IV/12(c). gekant en het geen geleentheid laat verbygaan om sy waardering vir die Hervormde Kerk aan sy studente te kenne te gee nie. Na sy ontslag het hy en sy gesin in Nice aan die Riviera gevestig waar hy aan die eerste uitgawe van sy Handboek der Dogmatiek gewerk het. Hy het die werk in 1895 voltooi. Daarna het hy as predikant in die Waalse Gemeente Haarlem gedien, van 1896 tot 1902. In 1902 het hy emeritaat aanvaar.

Muller het saam met L.E. Brandt van Nederland na SuidAfrika gereis. Brandt het pas aan die Universiteit van Utrecht sy teologiese studies voltooi, waar hy veral aanklank gevind het by Valeton, een van die bekende teoloë uit die etiese rigting. Brandt het vir 21 jaar (1916-1937) onafgebroke as voorsitter van die Algemene Kerkvergadering gedien en 'n leidende rol gespeel om die Fakulteit Teologie van kerklike kant te ondersteun. Hy is in 1939 oorlede. Brandt het die eerste omvattende poging aangewend om Hervormde teologie te tipeer (Oberholzer 1993:875). Brandt (1925) skryf soos volg:

Wij erkennen den Bijbel als Gods Woord, den regel van ons geloof, met een gezag boven dat van Formulieren van Eenigheid of andere formulieren, die door menschen zijn opgesteld, waarin wijvoor elk voorkomende geval een regel kunnen vinden. Daarom stellen wij ook niet een wet op van raak niet en smaak niet en roer niet aan, en leggen wij niet aan anderen regels op om te zeggen, dit mag niet en dat mag wel, maar prediken wij, dat ieder mensch in zijn eigen geweten ten volle verzekerd moet zijn en dat mijne vrijheid niet gebonden kan worden door het geweten van iemand anders, maar ook, dat mijne schuld niet kan vrijgepleit worden door wat een ander mensch geoorloofd acht.... Christus leeft in mij, en daartoe prediken wij de heden ten dage levende persoonlijkheid van Christus, niet alleen den historischen Christus, die 1900 jaar geleden op aarde gewandeld heeft, maar Jezus Christus, die nu nog elken dag naast ons staat.... Deze persoonlijke verhouding tot omgang met Jezus Christus komt tot stand door het geloof, die wonderlijke vereeniging van kennis en vertrouwen, waardoor wat objectief buiten ons waar is, als een persoonlijke overtuiging subjectief in ons opgenomen wordt. (pp. 106-117)

Muller het van 1904 tot 1909 Pretoria, Krugersdorp en die Witwatersrand bedien. In hierdie kort periode het hy met groot ywer die Hervormde Kerk opgebou, onder andere as voorsitter van die Algemene Kerkvergadering sedert 1907. Hy het talle openbare toesprake gelewer wat goed bygewoon is. Hy het hom ook beywer vir 'n eie teologiese opleiding. In die tyd het hy twee studente, te wete J.J. Kühn en J.J. Prinsloo, in sy pastorie opgelei en is hulle ook in die kerk beroepbaar gestel. Kühn het sy werk in Krugersdorp voortgesit. Muller was dus verantwoordelik vir die eerste formele opleiding van predikante in die Transvaal, nog voor die Fakulteit Teologie tot stand gekom het. As hy langer in Pretoria sou gebly het, sou hy waarskynlik nog meer studente opgelei het.

Die eerste uitgawe van Muller se Handboek der Dogmatiek ten dienste der Nedl. Hervormde Kerk het in 1895 verskyn. In die voorwoord (wat ook in die hersiene uitgawe van 1908 verskyn) verwys hy na sy 'gedwonge rustyd' wat hy benut het om ' $n$ handboek op te stel ten dienste van Hervormde 
studente en predikante. Hy gee erkenning aan die invloed van Lamers en sluit dan af met die woorde: 'Niets zal mij aangenamer zijn dan dan het getuigenis, met dezen arbeid de Nedl. Hervormde Kerk naar de maat mijner krachten te hebben gediend'. Terwyl hy in Pretoria was het hy die publikasie hersien en dit reflekteer in die tweede uitgawe se voorwoord, wat hy dateer 'Pretoria, 25 November 1907' (sien Voorbericht in Muller 1908).

Uit die titel en die voorwoord is dit duidelik dat Muller sy teologiese arbeid verstaan het as ten dienste van die kerk, en spesifiek die Hervormde Kerk. Muller, soos ander predikante vanuit die etiese rigting, was 'n kerklike teoloog met 'n passie vir die kerk en 'n duidelike begrip dat teologie slegs waarde het as dit ten dienste van die kerk staan. Met die lees van Muller se Handboek word dit gou duidelik dat hy oor 'n omvangryke kennis van die Kerkvaders, Middeleeuse teoloë asook die moderne teologie beskik het. Sy aanhalings uit die oorspronklike Hebreeuse, Griekse en Latynse tekste laat blyk dat 'kerklike teologie' op geen wyse as minderwaardig beskou kan word nie.

Muller se Handboek is deur die dosente van die Fakulteit Teologie vanaf 1917 tot en met die Tweede Wêreldoorlog as handboek gebruik. Daarom kom Mans (1967:493) tot die gevolgtrekking dat sy invloed op die ontwikkeling van Hervormde teologie omvangryk was, ten spyte daarvan dat hy net vyf jaar in Pretoria gewoon en gewerk het.

In sy kritiese beoordeling van Muller se teologiese bydrae, stel Mans dat Muller die Dogmatiek vanuit ' $n$ vooropgestelde eties-personalistiese uitgangspunt benader (sien Mans 1967:483-496). Hierdie uitgangspunt stel bepaalde antropologiese eise aan die Dogmatiek. Dit beteken dat Dogmatiek nie in die eerste plek 'n Godsleer op grond van die Skrif ontwikkel nie, maar eerder fokus op die Christelike geloofslewe wat die dogma voorafgaan. Die Bybel dien slegs indirek as bron vir die Dogmatiek, vir sover dit via die persoonlike geloofslewe ontsluit word. Daarom is ook die Filosofie en Psigologie bronne van die Christelike leer.

My persoonlike beoordeling is dat Muller (soos ander etiese teoloë) deur Schleiermacher beïnvloed is. Dit blyk onder andere uit Muller se verwysings na Schleiermacher in sy Handboek der Dogmatiek (Muller 1908:9, 34, 85, 114, 136, 179, 243). Dit word bevestig wanneer Muller daarop wys dat die Godsleer nie net berus op die Heilige Skrif nie, maar ook bepaal word deur die religieuse behoeftes van die mens.

Die hoofpunt van kritiek teen Muller se teologie vind ons in sy Christologie. Muller vind die twee-nature leer van Chalcedon problematies en verstaan Christus as Theanthropos, soos Origines (Mans 1967:488). Hieruit volg dat Muller 'n bepaalde verleentheid het met die maagdelike geboorte, Christus se neerdaling na die hel en die hemelvaart. Die menslike natuur word in Christus die Divinae capax, die Goddelike moontlikheid. Die goddelike karakter van die mens bestaan daarin dat hy langs ' $n$ geleidelike weg tot volmaaktheid kan kom. Wat nog verder ondersoek moet word, is dat ons spore van hierdie gedagtes by twee latere Hervormde teoloë kry, te wete AS Geyser (teen wie 'n klag geformuleer is oor die twee nature van Christus - Mans verwys op bl. 494 in 'n voetnota daarna) en JAAA Stoop wat in 1952 aan die Universiteit van Leiden onder leiding van Bakhuizen van den Brink oor die deificatio hominis gepromoveer het (sien Stoop 1952). Mans staan ook krities teenoor Muller se ekklesiologie, wat hy interpreteer in terme van 'n sinergisme. Die kerk bestaan nie net suiwer op grond van God se handeling nie, maar ook omdat die mens daarby betrokke is.

Mans (1967:494) verwys na SP Engelbrecht wat Muller se teologie beskryf het as 'eties-ortodoks'. Daarmee plaas beide Engelbrecht en Mans Muller binne die etiese rigting wat na 1870 soveel invloed in Nederland uitgeoefen het. Engelbrecht beskryf Muller wel as 'ortodoks', omdat Muller steeds erns gemaak het met die Bybel en sy teologie kerklik-konfessioneel ingeklee het. Mans verskil van Engelbrecht se beoordeling deur daarop te wys dat Muller beide die kerk en die belydenis se ontstaan in die menslike aanleg vind. Tegelykertyd onderstreep Mans dat hierdie soort 'afwykende' gedagtes nie veel aanklank in die Hervormde Kerk gevind het nie. Mans se positiewe beoordeling van Muller se teologie berus op die kerklike aard daarvan, die wetenskaplikheid daarvan asook die Christosentriese invalshoek van Muller se teologie.

\section{Ten slotte: Kerklike teologie?}

Uit die paar opmerkings oor Goddefroy en Muller se lewe en werk hierbo het dit duidelik geword dat hulle teologies van mekaar verskil het. Goddefroy het hom tuis gevoel in die konfessionele teologie met waardering vir teoloë vanuit die etiese rigting (bv. Van Oosterzee). Muller is deur die moderne teologie (en veral Schleiermacher) beïnvloed, maar het ook waardering vir die etiese rigting gehad. Hulle het duidelik in terme van Christologie verskil. Tog was beide predikant van die Hervormde Gemeente Pretoria; beide se nalatenskap in terme van die Hervormde teologie is belangrik en word met waardering onthou; beide het as voorsitter van die Algemene Kerkvergadering gedien; beide het hulle vir die onderwys beywer en beide het as Nederlanders besonder moeite gedoen met die opbou van die Hervormde Kerk. Miskien is die grootste gemene deler die invloed van die etiese teologie, insluitend hulle passie en liefde vir die kerk en die oortuiging dat hulle teologie in diens van die kerk en die verkondiging van die evangelie moet staan. Sou dit korrek wees om 'Hervormde teologie' as 'kerklike teologie' te beskryf? Sou dit die eenheid te midde van diversiteit verklaar?

Teologiese diversiteit kan tot ' $n$ bepaalde eenheid in die kerk saamvloei, omdat dit die kerk van Christus is, 'n liggaam waar elke liggaamsdeel 'n eie funksie het, 'n huis met baie kamers. Miskien moet ons Oscar Cullman se gedagtes ter harte neem, wat hy tydens 'n lesing in Januarie 1984 in die Petruskerk in Basel geformuleer het, toe hy gepraat het van 'der Einheit in der Vielheit', of te wel: 'Eenheid deur diversiteit' (Cullmann 1986:10). Cullman het beklemtoon dat die kerk eenheid en diversiteit moet omarm, want die Nuwe 
Testament getuig nie net van die eenheid in Christus nie, maar ook van die diversiteit in die Heilige Gees. Immers: Die Heilige Gees rus elke gelowige toe met unieke gawes, insigte en verantwoordelikhede (1 Kor. 12). Diversiteit is nie 'n swakheid nie, maar ' $n$ gawe tot opbou van die liggaam van Christus (Cullman 1986:18).

Teologiese navorsing en publikasie word nie net ter wille van die akademie en die universiteit beoefen nie. Die natuurlike habitat van teologie is eintlik nie die universiteit nie, maar die kerk en meer spesifiek - die erediens (Barth s.a. [1925]). Elke preek wat elke Sondag gelewer word vloei voort vanuit 'n bepaalde teologie. Elke preek weerspieël die prediker se teologie (of gebrek aan teologie). Dit is 'n groot uitdaging om die balans tussen kerk en teologie te handhaaf. Barth (KD 1/1) is na my mening korrek as hy skryf:

Dogmatik ist als theologische Disziplin die wissenschaftliche Selbstprüfung der christlichen Kirche hinsichtlich des Inhalts der ihr eigentümlichen Rede von Gott ... Dogmatik ist eine theologische Disziplin. Theologie ist aber eine Funktion der Kirche. (p. 302)

Teologie is in die eerste plek ' $n$ funksie van die kerk. Eberhard Busch (2010:13) tipeer Barth se verstaan van teologie as, vreugdevolle diens aan God en Sy kerk'. Deeglike, wetenskaplike teologiese opleiding is deel van die reformatoriese tradisie, deel van die Hervormde tradisie en krities belangrik vir die welwese van die kerk. Wanneer teologie van die kerk vervreemd raak, word dit in baie opsigte irrelevant.

A.J. Bronkhorst het op 20 Oktober 1954 sy professorale intreerede gelewer aan die Protestantse Theologische Faculteit Brussel oor 'Kerk en Theologie' (Bronkhorst 1954). Hy stel die vraag radikaal (bl. 3): 'Wat heeft de gemeente van Jezus Christus te maken met een theologischen fakulteit?' Sy vertrekpunt is ubi Christus, ibi ecclesia. Waar Christus is, waar Christus verkondig word, waar Christus gevolg word, daar is die kerk. Waarom verwag die kerk so baie van die teologie, en spesifiek teologiese opleiding aan ' $n$ universiteit? Omdat die kerk soveel verwag van die Woord van God. Teologie is nie ' $n$ fraai ornament wat die huis versier nie, dit is wesenlik belangrik en noodsaaklik. Omdat die kerk erns maak met die Woord van God is goed opgeleide predikante, met voldoende wetenskaplike kennis en teologiese insig, lewensnoodsaaklik (Bronkhorst 1954:9-10).

\section{Erkenning \\ Mededingende belange}

Die outeur verklaar dat hy geen finansiële of persoonlike verbintenis het met enige party wat hom nadelig kon beïnvloed het in die skryf van hierdie artikel nie.

\section{Literatuurverwysings}

Barth, K., s.a. [1925], 'Kirche und Theologie', in Die Theologie und die Kirche Gesammelte Vortrage Band II, bl. 302-328, Evangelischer Verlag, Zollikon-Zürich.

Beukes, C.J., 2008, 'Voices carry: An archaeology of the Hervormd approach', HTS Teologiese Studies 64(1), 73-109.

Beukes, J., 2000, "n Postmoderne redekritiek vir kerk en teologie', PhD dissertasie, Fakulteit Teologie, Universiteit van Pretoria.

Botha, S.J., 1979, Ds. Marie Joseph Goddefroy 1848-1920, HAUM, Pretoria.

Botha, S.J., 1981, Ds. Marie Joseph Goddefroy 1848-1920, HAUM, Pretoria.

Botha, S.J., 1890 [1990], 'Verantwoording', in M.J. Goddefroy (ed.), Die kerkkwessie nie 'n leer - nie maar 'n lewenskwessie, vertaal deur SJ Botha, KITAL, Pretoria.

Brandt, L.E., 1925, 'Onze tradities en gewoonten', in Almanak voor die Nederduitsch Hervormde Kerk van Afrika Jg. 19, Red. S.P. Engelbrecht, bl. 106-117.

Bronkhorst, A.J., 1954, Kerk en Theologie, Boekencentrum N.V., s'-Gravenhage.

Buitendag, J., 2017, 'Boodskap van die Dekaan', in Gateway to... Oopmaak van die hekke..., Fakulteit Teologie (Universiteit van Pretoria) Eeufees Publikasie, bl. 11-14, Chrysalis Printing and Publishing Solutions, Pretoria.

Busch, E., 2010, The great passion. An introduction to Karl Barth's theology, William B. Eerdmans Publishing Company, Grand Rapids, MI.

Cullmann, O., 1986, Unity through diversity, Fortress Press, Philadelphia, PA.

Dreyer, W.A., 1999, Nederduitsch Hervormde Kerk van Afrika - die eerste 250 jaar, KITAL, Pretoria.

Dreyer, W.A., 2014, 'Wanneer een twee word: 'n Perspektief op resente gebeure in die Nederduitsch Hervormde Kerk van Afrika', HTS Teologiese Studies/ Theological Studies 70(1), Art. \#2054, 1-16. https://doi.org/10.4102/hts.v70i1.2054

Duncan, G. (Red.), 2017, Gateway to... Oopmaak van die hekke..., Fakulteit Teologie (Universiteit van Pretoria) Eeufees Publikasie, Chrysalis Printing and Publishing Solutions, Pretoria.

Engelbrecht, B.J, 1953a, 'Prof. P.J. Muller as Dogmatikus', HTS Teologiese Studies 9(3 \& 4), 271-282.

Engelbrecht, S.P., 1953b, Geskiedenis van die Nederduistsch Hervormde Kerk van Afrika, H.A.U.M., Kaapstad.

Goddefroy, M.J., 1890 [1990], Die kerkkwessie nie 'n leer-nie maar'n lewenskwessie, vertaal deur SJ Botha, KITAL, Pretoria.

Haitjema, Th.L., 1931, 'Zestig jaren Nederlandsche Theologie', in Onder eigen vaandel, Zesde Jaargang, bl. 31-44, Red. Th.L. Haitjemea \& A.B. Te Winkel, H. Veenman \& Zonen, Wageningen.

Haitjema, Th.L., 1964, De nieuwere geschiedenis van Neerlands Kerk der Hervorming. Van Gereformeerde Kerkstaat tot Christus-belijdende Volkskerk, Boekencentrum N.V, 's-Gravenhage.

Koekemoer, J.H., 1994, Die idioom van die Nederduitsch Hervormde Kerk - 'n Teologiese vraag, HTS Teologiese Studies/Theological Studies 50(1/2), 14-26. https://doi.org/10.4102/hts.v50i1/2.2540

Loader, J.A., 1984, 'Die etiese Ou-Testamentici in Nederland tussen 1870 en 1914', ongepubliseerde DD-dissertasie, Unisa.

Loader, J.A., 1987, 'Tertium Datur - Oor die Etiese waarheidsbegrip', HTS 43(1 \& 2), 47-56.

Mans, C.J., 1967, Die lewe en werk van die dogmatikus P.J. Muller, doktorale proefskrif ingedien in die Fakulteit Godgeleerdheid, Universiteit van Pretoria.

Muller, P.J., 1908, Handboek der Dogmatiek ten dienste der Ned. Hervormde Kerk, $2^{\mathrm{e}}$ Druk, J.B. Wolters, Groningen.

NHKA, 2016, Notule van die $71^{e}$ Algemene Kerkvergadering, Kerkargief, Pretoria.

Oberholzer, J.P., 1992, 'Die Fakulteit Teologie (Afd A) aan die Universiteit van Pretoria: Vrae oor sy identiteit en problematiek', HTS Teologiese Studies 48(1 \& 2), 493-504.

Oberholzer, J.P., 1993, 'Die teologiese eie-aardigheid van die Nederduitsch Hervormde Kerk: Vrae en nuanses', HTS Teologiese Studies 49(4), 870-886.

Oberholzer, J.P., 2010, 'Honderd Jaar Kerk en Teologiese Opleiding: 'n Kroniek van die Hervormde Kerk Deel 1', HTS Teologiese Studies Supplementum 9

Pont, A.D., 1955, Nicolaas Jacobus van Warmeloo 1835-1892, Drukkerij en Uitgeversmaatschappij v/h Kemink \& Zoon N.V, Utrecht.

Rasker, A.J., 1974, De Nederlands Hervormde Kerk vanaf 1795. Haar gesciedenis en theologie in de negentiende en twintigste eeuw, Uitgeversmaatschappij J.H. Kok, Kampen.

Snyman, G., 2015, 'Totius: die ironie van vergewe en vergeet', in Litnet Akademies (Godsdienswetenskappe), op 20 Maart 2017 besoek http://www.litnet.co.za/ totius-die-ironie-van-vergewe-en-vergeet/

Stoop, J.A.A.A., 1952, Die deificatio hominis in die sermones en epistulae van Augustinus, Leiden, Drukkerij 'Luctor et Emergo'.

Van Aarde, A.G., 2017, Journals and Publications, in Gateway to... Oopmaak van die hekke..., Fakulteit Teologie (Universiteit van Pretoria) Eeufees Publikasie, bl. 70-71, Chrysalis Printing and Publishing Solutions, Pretoria.

Van Wyk, D.J.C. (Red.), 1999, $20^{\text {ste }}$ Eeuse Hervormde Teologie, SENTIK, Pretoria. 